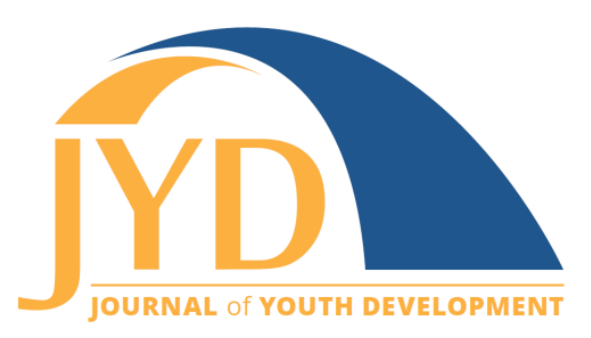

http://jyd. pitt. edu/ | Vol. 14 Issue 2 DOI 10.5195/jyd.2019.770 | ISSN 2325-4017 (online)

\title{
Immigration: How It Affects Our Lives
}

\section{Miski Mohamed}

\begin{abstract}
Immigrant youth are often tasked with balancing the cultures of 2 different places, the culture of their heritage and American culture. While immigrant parents want their children to succeed and thrive in the United States, this often comes at the cost of losing important insight about the context and circumstances surrounding a family's immigration journey. This youth author explains that acculturation, but not assimilation is important because learning and understanding the history of countries of origin helps to make more informed and conscious citizens.
\end{abstract}

Key words: Somali American, youth, immigration

As children of immigrants, there are many expectations that come with being an American citizen while also staying true to the nationality and culture of the country our parents came from. In our case it is being children of Somali immigrants in Minnesota, the state that is home to the largest population of Somali immigrants and their children. Although we live in Minnesota, there is a lack of unity and impartiality among the Somali community that dates back to before our parents settled here. Our Somali parents went through so many struggles to come to America, but it seems as though clans and tribalism are still drifting us apart. The Somali-American youth values the idea of being a part of a tribe, whether it be a major one such as Hawiye or a minor one like Yibir. Tribalism is the main cause of the civil war that led to the immigration of Somalis to America, and also the estrangement of Somalia citizens. SomaliAmerican youth are given the opportunity of not having to live in a war-torn country, yet many are exhibiting the same damaging mindset that led to the destruction of our country and migration of our parents. Rather than taking advantage of the fact that they were born in a country that values democracy and freedom, our peers are holding onto the mindset that tears us even farther apart. Being a Somali-American young person there are many possibilities that await us: being able to change the perspective that Americans have on immigration, educate

(c) $\mathrm{EY}_{\mathrm{EY}}$ New articles in this journal are licensed under a Creative Commons Attribution 4.0 License. This journal is published by the University Library System, University of Pittsburgh and is cosponsored by the University of Pittsburgh Press. The Journal of Youth Development is the official peer-reviewed publication of the National Association of Extension 4-H Agents and the National AfterSchool Association. 
the Somali community on why tribalism is so destructive, plan for a better future for Somali immigrants and their children, and other possibilities if the Somali-American youth knew their potential.

Although associating with our Somali heritage is important, it is equally important to remember that as Somali-American youth we are responsible for our American citizenship, privileges, and rights. Many of the children of Somali immigrants don't take advantage of the rights that their parents might not have if they are not naturalized citizens, such as voting and even being able to run for public office. Also being able to obtain an amazing education, especially in Minnesota where public education is better, as compared to other states in the United States.

Many of the Somali youth are not aware of the privileges they have from just being born in America. A big problem being that as Americans we are responsible for being involved in politics and knowing how important the civil liberties and rights we are guaranteed are. There is so much potential and privileges that Somali-American youth have that children living in Somalia right now don't. American youth might not be given a formal voice until they are 18 years old, but that should not stop them from being engaged in political culture that affects them day-today. Whether it be interacting with our elected officials or standing up for the issues that important to us, including immigration and most importantly the travel ban proposed by our president. Being the children of Somali immigrants, our voice is needed so our representatives are aware of the changes that we want. It is our responsibility to take advantage of the life our parents wanted for us when they moved here. Whether that includes rewriting the history of discord between tribes or having the political efficacy that American citizens should have, the future is in the hands of the Somali-American youth. 